\section{LIIKKEEN LUOVUTUKSEN VAIKUTUKSET KILPAILUKIELTOSOPIMUKSIIN}

\section{THE EFFECTS OF A TRANSFER OF AN UNDERTAKING ON NON-COMPETE AGREEMENTS}

\section{Jenna Helenius ${ }^{1}$}

DOI: https://doi.org/10.33344/vol14iss1pp50-73

Helsinki Law Review, 1/2020, pp. 50-73

(c) 2020 Pykälä ry, Mannerheimintie 3 B, 5th floor, 00100 Helsinki, Finland, and the author.

\section{VERTAISARVIOITU
KOLLEGIALT GRANSKAD
PEER-REVIEWED
www.tsv.fittunnus}

\section{Avainsanat:}

työoikeus, liikkeen luovutus, työsuhteen ehtojen muutos, kilpailukieltosopimus

\section{Keywords:}

employment law, transfer of undertakings, changing of the terms of employment, non-compete agreement

\section{ABSTRACT}

This article aims to analyze and systemize the legal regime concerning the effects of a transfer of undertakings on non-compete agreements. As a rule, when an undertaking is transferred, the rights and obligations arising from the existing employment relationships should transfer to the transferee as such. However, for the non-compete agreements to be valid, employers should also have sufficient grounds when invoking the non-compete agreements.

Non-compete agreements are valid between the parties of the employment contracts. Therefore, the determination of who is to be considered as the employer can affect whether the noncompete agreements should transfer to the transferee as such. The acceptable grounds for the conclusion of the non-compete agreements are versatile, and agreements based on different grounds may act differently due to transfer. Hence, the transfer of non-compete agreements to the transferee should not be considered automatic as a principle, but rather conditional.

1 Jenna Helenius is an LL.M. student at the University of Helsinki. This article is based on the author's Bachelor's Thesis.

\section{JOHDANTO}

Artikkelissa tarkastellaan liikkeen luovutuksen vaikutuksia työntekijän kilpailukiellosta johdettuun kilpailukieltosopimukseen. Pääsääntönä liikkeen luovutuksessa on, että tällöin työnantajan työsuhteista johtuvat oikeudet ja velvollisuudet siirtyvät sellaisenaan uudelle työnantajalle. Työsuhdetta normittavat kuitenkin perussuhdeteorian ${ }^{2}$ mukaisesti eri säännöstyskeinoista johtuvat normit, jotka reagoivat eri tavoin liikkeen luovutustilanteessa. Työsopimuksen kautta työsuhdetta normittavan kilpailukieltosopimuksen siirtymiseen vaikuttaa lisäksi sille laissa asetettu erityisen painavan syyn vaatimus.

Tässä kirjoituksessa pyritään selvittämään, mitkä ovat liikkeen luovutuksen vaikutukset kilpailukieltosopimuksiin. Työsopimuslain (55/2001, "TSL") sisällä voidaan nähdä ristiriita liikkeen luovutusta sekä kilpailukieltosopimusta koskevien säännösten välillä. Yhtäältä työsuhteen ehtojen tulisi siirtyä sellaisenaan uudelle työnantajasubjektille, kun taas toisaalta työsopimuslaki edellyttää myös uudelta työnantajasubjektilta erityisen painavaa perustetta kilpailukieltosopimukseen vedotessaan. ${ }^{3}$ Kilpailukieltosopimusten käyttö on viime aikoina yleistynyt työsuhteissa. ${ }^{4}$ Tämä ilmentää yhteiskunnan muutosta ja erityisesti työn muutosta kohti palvelu- ja asiantuntijatyötä. Työnantajien liiketoimintamalli perustuu yhä useammin tietoon, osaamiseen, teknologiaan ja sitä kautta liikesalaisuuksiin sekä luotuihin asiakassuhteisiin $^{\mathbf{5}}$, eikä enää entiseen tapaan kalliiden tuotantovälineiden omistukseen. Siten myös tarve suojata näitä uusia "tuotantovälineitä" on kasvanut. ${ }^{6}$ Tästä syystä on tärkeää selventää kilpailukieltosopimusten kohtelua liikkeen luovutustilanteissa erityisesti, kun lainsäädännöstä saatava ohjaus näiden keskinäissuhteesta ei ole yksiselitteinen.

Kirjoitus rajautuu koskemaan liikkeen luovutustilanteita, jossa itse liikkeen luovutuksen tunnusmerkistön täyttymisestä ei ole epäselvyyttä. Kirjoituksen ulkopuolelle jää siten suurilta osin EU-aineisto ${ }^{7}$, lisäksi kilpailukieltosopimusten pätevyyteen liittyvät kysymykset tulee

2 Arvo Sipilän teoksessaan "Suomen työoikeuden käsite ja järjestelmä sekä suhde sosiaaliseen lainsäädäntöön" (1938) luoma työsuhteeseen perustuva teoria voidaan nähdä työoikeuden oikeudenalakehityksen alkuna. Teoriaa kehitti edelleen Jorma Vuorio teoksessaan "Työsuhteen ehtojen määrääminen" (1955), jossa hän selitti työsuhteen ehtojen määräytymistä ja muutosta säännöstyskeino-opin kautta. Sipilä, Arvo: Suomen työoikeuden käsite ja järjestelmä sekä suhde sosiaaliseen lainsäädäntöön. Helsinki 1938 (Sipilä 1938) sekä Vuorio, Jorma: Työsuhteen ehtojen määrääminen. Suomalaisen lakimiesyhdistyksen julkaisuja B-sarja N:o 76. Turku 1955. (Vuorio 1955).

3 Hallituksen esitys työsopimuslaiksi ja eräiksi siihen liittyviksi laeiksi (HE 157/2000 vp), s. 82.

4 Työ- ja elinkeinoministeriön tutkimuksia 18/2018, Selvitys kilpailukielto- ja salassapitosopimusten käytöstä, Ahtela, Jukka, 2018 (TEM 18/2018), s. 48.

5 TEM 18/2018, s. 15.

6 Vapaavuori, Tom: Yrityssalaisuudet, liikesalaisuudet ja salassapitosopimukset. Alma Talent Oy, Yhteistyössä Lakimiesliiton Kustannus, Helsinki 2016 (Vapaavuori 2016), s. 15-16.

7 Euroopan unionin tuomioistuimen ("EUT") ratkaisukäytännössä käsitellään laajasti liikkeen luovutuksen tunnusmerkistöä. Lisäksi suoranaisesti tässä kirjoituksessa käsiteltyä aihetta koskevia EUT:n ratkaisuja 
muutoinkin ratkaista pääsääntöisesti kansallisen lain nojalla ${ }^{\mathbf{8}}$. Vaikka kilpailukieltosopimukset ovat tavanomaisia toimitusjohtajasopimuksissa, näitä ei kuitenkaan käsitellä, sillä tällöin ei ole kyse työsuhteesta. ${ }^{9}$ Tästä johtuu myös, ettei toimitusjohtajan sopimussuhteen katsota edes siirtyvän liikkeen luovutuksessa. ${ }^{10}$ Kilpailukieltosopimusten osalta tarkastellaan nimenomaan työsopimussuhteen alussa taikka työsuhteen kestäessä solmittuja kilpailukieltosopimuksia ja siten tarkastelun ulkopuolelle rajataan työsuhteen jälkeiset kilpailukieltosopimukset, joihin sovelletaan pääsääntöisesti lakia varallisuusoikeudellisista oikeustoimista (228/1929). ${ }^{11}$

Kirjoituksen tavoitteena on jäsentää ja systematisoida olemassa olevaa oikeudentilaa liikkeen luovutustilanteiden vaikutuksesta kilpailukieltosopimuksiin sekä tuoda esille kilpailukieltosopimuksen erityisluonne suhteessa muihin työsuhteen ehtoihin liikkeen luovutuksen yhteydessä. Lähdeaineistona on käytetty lainvalmisteluaineiston ja oikeuskirjallisuuden lisäksi työ- ja elinkeinoministeriön sekä työmarkkinaosapuolten ohjeita ja selvityksiä. Kirjoituksessa tulkitaan myös oikeuskäytäntöä, vaikka ratkaisuja aiheesta onkin rajoitetusti. ${ }^{12}$ Kirjoituksen lopussa esitetään myös oikeuspoliittisia kannanottoja oikeustilan selkiyttämiseksi.

\section{LIIKKEEN LUOVUTUKSEN VAIKUTUKSET TYÖSUHTEEN EHTOIHIN}

\section{I Liikkeen luovutuksesta johtuvat työsuhteen ehtojen muutokset}

Liikkeen luovutustilanteiden vuoksi työsopimuslakiin on otettu määräys siitä, miten työsuhteen ehdot siirtyvät. Siirtymisellä ei kuitenkaan voida selittää sitä, miten ja miksi työsuhteen ehdot voivat myös muuttua liikkeen luovutuksen vuoksi. Tässä kappaleessa käsitellään liikkeen luovutuksen vaikutusta työsuhteen ehtoihin sekä sitä, miten ehdot voivat tässä yhteydessä myös muuttua, jotta myös kilpailukieltosopimuksen käytöstä liikkeen luovutustilanteessa voidaan ymmärtää.

\section{ei ole annettu}

Heiskanen, Jussi: Kilpailukieltosopimuksen edellytykset työsopimuslain mukaan. Teoksessa Jalanko, Risto - Siiki, Marika (toim.) Helsingin hovioikeuden julkaisuja - Kirjoituksia työoikeudesta, s. 129-143. Hakapaino Oy, Helsinki 2009. (Heiskanen 2009), s. 129

9 Hietala, Harri - Kaivanto, Keijo: Työsopimus jajohtajasopimus. Alma Talent Oy Yhteistyössä Lakimiesliiton Kustannus, Helsinki 2017. (Hietala - Kaivanto 2017), s. 14

10 Hietala, Harri - Kaivanto, Keijo - Pystynen, Johanna - Valvisto, Elisa: Esimiehen työoikeus. Alma Talent Oy, Helsinki 2020. Verkkojulkaisu, Alma Talent Fokus, päivitetty 3.4.2020, tarkistettu 21.5.202O. (Hietala - Kaivanto - Pystynen - Valvisto 2020), Kilpaileva toimita; Kilpailukieltosopimus.

11 Koskinen, Seppo - Nieminen, Kimmo - Valkonen, Mika: Työhönotto ja työsopimuksen ehdot. Talentum, Helsinki 2008. (Koskinen - Nieminen - Valkonen 2008), s. 462

12 Koskinen, Seppo: Kilpailukieltosopimuksiin liittyviä erityiskysymyksiä - moninaiset työsuhteet, sopimussuhteen muutokset, työsuhteen päättäminen. Edita publishing Oy, 2004. (Koskinen 2004), s. 20. Kilpailukieltosopimuksen työsuhteen jälkeisen voimassaoloajan puitteissa (pääsääntöisesti 6 kk) ei useinkaan ehditä saamaan asiassa tuomioistuinratkaisuja. Tämä on osaltaan syy sille, että osapuolten intresseissä ei useinkaan ole hakea asiaan ratkaisua yleisestä tuomioistuimesta.
Vaikka TSL 1:10.1:n määritelmä ei vastaa sanamuodoltaan täysin liikkeenluovutusdirektiivin (2001/23/EY) määritelmää, on tätä kuitenkin hallituksen esityksen mukaan tarkoitettu. ${ }^{13}$ Liikkeenluovutusdirektiivin pyrkimyksenä on yhtenäistää eurooppalaista sääntelyä. Se on kuitenkin luonteeltaan vain vähimmäisdirektiivi ja siten jäsenvaltiot voivat halutessaan säätää työntekijän kannalta liikkeenluovutusdirektiiviä edullisemmin. ${ }^{14}$ Liikkeen luovutuksesta seuraaviin työoikeudellisiin kysymyksiin on Suomessa keskitytty jo ennen nykyisen liikkeenluovutusdirektiivin ja sitä edeltäneiden direktiivien aikaa. ${ }^{15}$

Työsuhteen oikeudet ja velvollisuudet eli työsuhteen ehdot siirtyvät liikkeen luovutuksensaajalle automaattisesti ja pakottavasti. ${ }^{16}$ TSL 1:10.2:n pääsäännön mukaan ...liikkeen luovutuksessa työnantajan luovutushetkellä voimassa olevista työsuhteista johtuvat oikeudet ja velvollisuudet sekä niihin liittyvät työsuhde-etuudet siirtyvät liikkeen uudelle omistajalle tai haltijalle. ${ }^{17}$ Liikkeen luovutusta koskevan sääntelyn yhtenä tavoitteena on työntekijöiden oikeuksien turvaaminen ja työsuhteen ehtojen pysyttäminen ennallaan, tapahtuuhan liikkeen luovutus työntekijöistä riippumatta. ${ }^{18}$ Sääntelyn voi nähdä ilmentävän osaltaan työntekijän suojelun periaatetta, jonka mukaan työntekijää työsuhteen heikompana osapuolena tulee suojata pakottavalla lainsäädännöllä. ${ }^{19}$ Työntekijän suojelun voidaankin nähdä yhtenä työoikeudellisen sääntelyn tavoitteena sekä lähtökohtana. ${ }^{20}$ Työntekijän työsuhteen taikka työsopimuksen ehtojen ei siten tulisi ainakaan huonontua liikkeen luovutuksesta johtuen. ${ }^{21}$

Liikkeen luovutusdirektiivin tavoitteet on huomioitava niin lainvalmistelussa kuin kansallisessa ratkaisutoiminnassakin. Sääntelyn tavoitteena ei kuitenkaan ole taata siirtyville työntekijöille yhdenmukaisen tasoista suojaa koko unionin alueella, vaan työntekijää on tarkoitettu suojattavan suhteessa luovutuksensaajaan samalla tavalla kuin häntä suojataan suhteessa

13 HE 157/2000 vp. s. 65-67. Ks. 2001/23/EY 1 art. määritelmä. Liikkeen luovutuksen tunnusmerkistö on täsmennetty myös EUT:n ratkaisukäytännössä, ks. asia C-24/85 Jozef Maria Antonius Spijkers v Gebroeders Benedik Abattoir CV and Alfred Benedik en Zonen BV. ECLI:EU:C:1986:127.

14 Kuten esim. TSL 1:10.2:n "...työsuhteista johtuvat oikeudet ja velvollisuudet sekä niihin liittyvät työsuhde-etuudet siirtyvät liikkeen uudelle omistajalle tai haltijalle." seuraa (2001/23/EY) 8 artiklasta (kursivointi lisätty).

15 Tiitinen, Kari-Pekka - Kröger, Tarja: Työsopimusoikeus. Talentum, Helsinki 2012. (Tiitinen - Kröger 2012), s. $403-404$.

16 Siirron automaattisuus ja pakottavuus on vahvistettu myös EUT:n ratkaisukäytännössä esim. asia C-362/89. Giuseppe d'Urso, Adriana Ventadori and others v Ercole Marelli Elettromeccanica Generale SpA and others. EU:C:1991:326.

17 Kyseinen säännös vastaa liikkeen luovutusdirektiivin (2001/23/EY) 3 art. 1 kohtaa.

18 Liikkeen luovutusdirektiivin (2001/23/EY) kolmas perustelukappale, ks. lisää direktiivin tavoitteista Watson, Philppa: EU Social and Employment Law. Oxford University Press, Oxford 2014. (Watson 2014) W.140-141.

19 Periaatteen voidaan nähdä juontuvan perustuslain (713/1999) $18.1 \S$ toisesta virkkeestä.

20 Bruun, Niklas - von Koskull, Anders: Työoikeuden perusteet. Alma Talent Oy, Helsinki 2012. Verkkojulkaisu, Alma Talent Verkkokirjahylly, tarkistettu 18.5.202O. (Bruun - von Koskull 2012), s. 2O-21.

21 Ilmenee mm. asiassa C-105/84. Foreningen af Arbejdsledere i Danmark v A/S Danmols Inventar, in liquidation. EU:C:1985:331. 
luovuttajaan kansallisten oikeussääntöjen nojalla. ${ }^{22}$ Siten kilpailukieltosopimuksia koskeva kansallinen sääntely määrittelee pääsääntöisesti sen, miten ne käyttäytyvät liikkeen luovutuksen yhteydessä.

Työsuhteen ehtojen siirtyminen sellaisenaan liikkeen luovutuksen yhteydessä ei ole kuitenkaan poikkeuksetonta. ${ }^{\mathbf{2 3}}$ Vaikka liikkeen luovutus ei itsessään voi olla peruste työsuhteen ehtojen muuttamiselle, voivat työehdot liikkeen luovutuksen yhteydessä käytännössä muuttua. ${ }^{\mathbf{2 4}}$ Työsuhteen ehdot voivat muuttua ensinnäkin työnantajan ja työntekijän keskinäisellä sopimuksella. Liikkeen luovutustilanteissa ei kuitenkaan voida velvoittaa työntekijää solmimaan luovutuksensaajan kanssa uutta työsopimusta. ${ }^{25}$ Siten luovutuksensaaja ei voi liikkeen luovutuksen yhteydessä myöskään velvoittaa siirtynyttä työntekijää uuden kilpailukieltosopimuksen solmimiseen.

Työnantajan yksipuolisella ilmoituksella voidaan muuttaa työsuhteen ehtoja myös liikkeen luovutustilanteiden yhteydessä. ${ }^{26}$ Niin oikeuskäytännössä ${ }^{27}$ kuin oikeuskirjallisuudessakin ${ }^{\mathbf{2 8}}$ on vakiintunut kanta, jonka mukaan työnantaja voi muuttaa työsuhteen ehtoja yksipuolisesti joko direktio-oikeutensa ${ }^{29}$ nojalla tai, jos kyseessä on työsuhteen olennainen ehto irtisanomisperusteella irtisanomisaikaa noudattaen. Esimerkiksi työntekopaikkaa koskevat työsopimuksen määräykset saattavat liikkeen luovutuksen yhteydessä muuttua, erityisesti kun liikkeen luovutustilanteissa uudella työnantajalla on tavallista useammin irtisanomisperusteinen oikeus myös työsuhteen olennaisten ehtojen yksipuoliseen muuttamiseen. ${ }^{\mathbf{3 0}}$

Myös työsuhteessa noudatettava työehtosopimus voi liikkeen luovutuksen johdosta muuttua. Se, mitä työehtosopimusta työntekijöiden työsuhteissa noudatetaan, riippuu työnantajasta. Mikäli

22 Ks. esim. C-105/84 Foreningen af Arbejdsledere i Danmark v A/S Danmols Inventar, in liquidatio kohta 26. ECLI:EU:C:1985:331.

23 Murto, Jari: Ryhmänormit yrityksessä. Suomalainen lakimiesyhdistys, Helsinki 2015. (Murto 2015) s. 50.

24 HE 157/2000 vp, s. 105-106.

25 Valkonen, Mika: 13. Liikkeen luovutus. Teoksessa Koskinen, Seppo - Kairinen, Martti - Nieminen Kimmo - Nordstöm, Kim - Ullakonoja, Vesa - Valkonen, Mika: Työoikeus III. Alma Talent Oy, Helsinki 2019. Verkkojulkaisu, Alma Talent Fokus, päivitetty 22.1.2019, tarkistettu 13.5.2020. (Valkonen 2019), Oikeuksien ja velvollisuuksien siirtyminen; Automaattisesti ja pakottavasti.

26 Kärkkäinen, Mika - Äimälä, Markus: Työsopimuslaki. Alma Talent Oy, Yhteistyössä Lakimiesliiton Kustannus, Helsinki 2017. (Kärkkäinen - Äimälä 2017), s. 336-337.

27 Esimerkiksi TT 2014-103 sekä KKO 1996:89.

28 Näin mm. Engblom, Matleena: Työsuhteen ehdot, määräytyminen, tulkinta ja muuttaminen. Alma Talent Oy, Helsinki 2013. (Engblom 2013), s. 124 sekä Tiitinen - Kröger 2012, s. 820-832.

29 Työnantajan direktio-oikeudella tarkoitetaan työnantajan oikeutta johtaa ja valvoa työntekoa. Se pitää sisällään työnantajan oikeuden määrätä mm. siitä miten ja missä työ suoritetaan. Oikeus on johdettu TSL 3:1:sta. Direktio-oikeutta rajaa mm. laki, hyvä tapa ja työsopimuksen sisältö.

30 Kärkkäinen - Äimälä 2017, s. 336-337. Työnantajalla voi liikkeen luovutuksesta seuraavan organisaatiomuutoksen johdosta olla esim. peruste tuotannollistaloudelliselle irtisanomiselle. luovutuksensaaja on osallisena tai sidottuna toiseen työehtosopimukseen kuin liikkeen luovuttaja, noudatetaan luovuttajaa sitovaa työehtosopimusta sen voimassaoloajan loppuun saakka. Luovutuksensaajaa sitovaa työehtosopimusta aletaan noudattaa siirtyneiden työntekijöiden työsuhteissa vasta luovuttajaa sitoneen työehtosopimuksen voimassaolon päätyttyä. ${ }^{\mathbf{3 1}}$

Liikkeen luovutuksen yhteydessä siirtyviä työsuhteen ehtoja tulee arvioida tapauskohtaisesti. Arvioitaessa ehtojen siirtymistä tulee ottaa huomioon säännöksen tarkoitus, työntekijän oikeuksien turvaaminen sekä toisaalta liikkeen luovutuksen osapuolten intressit sekä käytännön realiteetit. ${ }^{32}$ Pelkästään työntekijän suojelun periaatteen nojalla ei voida velvoittaa luovutuksensaajaa säilyttämään esimerkiksi työpaikkaruokailua, jos luovutuksensaajalla ei tällaista ole ennen luovutusta ollut käytössään. ${ }^{33}$ Työntekijälle on kuitenkin annettu poikkeuksellinen oikeus ehtoheikennysten varalta. TSL 7:6:n mukaan, jos työsuhteen ehdot heikentyvät olennaisesti liikkeen luovutuksen johdosta, työntekijällä on oikeus päättää työsuhde sellaisin vaikutuksin, että työnantajan katsotaan olevan vastuussa sen päättymisestä.

\subsection{Työnantajalle kuuluvien oikeuksien siirtyminen luovutuksensaajalle} Kilpailukieltosopimus tulee nähdä ennen kaikkea työnantajan oikeutena ${ }^{\mathbf{3 4}}$, sillä sen tarkoituksena on suojata työnantajan intressejä, kuten kilpailuasemaa. Jotta kysymykseen kilpailukieltosopimuksen siirtymisestä liikkeen luovutuksen yhteydessä voidaan vastata, on arvioitava erikseen työnantajan työsuhteesta johtuvien oikeuksien siirtymistä luovutuksensaajalle.

Työsuhde synnyttää sekä työnantajalle että työntekijälle oikeuksia ja velvollisuuksia. Liikkeen luovutuksen yhteydessä siirtyvät, työnantajan työsuhteista johtuvat oikeudet ovat usein käänteisesti työntekijän velvollisuuksia. Liikkeen luovutusta koskeva säännös on siten ikään kuin poikkeus siihen, ettei työsuhteesta johtuvia oikeuksia tai velvollisuuksia saa siirtää eteenpäin ilman toisen osapuolen suostumusta. ${ }^{35}$ Työntekijän pääasialliset velvollisuudet on työsopimuslaissa jäsennetty sen kolmanteen lukuun. Näitä ei kuitenkaan luetella tyhjentävästi vaan työntekijän velvollisuuksien käsite työsuhteessa on kyseistä lukua laajempi. Velvoitteita voi syntyä pelkästään työnantajan työnjohto- ja valvontavallan johdosta, minkä lisäksi työntekijän velvoitteita on sisällytetty muuhun lainsäädäntöön. ${ }^{{ }^{36}}$

31 Työehtosopimuslain (436/1946) 5 \& ja KKO 2009:28

32 Ks. Asia C-499/04 Hans Werhof v Freeway Traffic Systems GmbH \& Co. KG. EU:C:2006:168, kohta 31 ja C-426/11 Asia C-426/11 Alermo-Hetton ym. v Parkwood Leisure Ltd. EU:C:2013:521, kohta 25.

33 Kärkkäinen - Äimälä 2017, s. 337.

34 KKO 2005:50 perustelujen kohta 10.

35 TSL 1:7.1, jonka perusteista ks. esim. hallituksen esitys työsopimuslaiksi ja laiksi huoneenvuokralain muuttamisesta (HE 228/1969 vp), s. 3 .

36 Esim. työturvallisuuslakiin (738/2002). 
Työntekijälle työsuhteesta johtuvia velvollisuuksia säännöstelevät niin ikään eri normilähteet. Työntekijän päävelvoite on työnteko työnantajan lukuun. ${ }^{37}$ Käänteisesti työnantajalla on oikeus palkan suorittamista vastaan saada työntekijän työvoima käyttöönsä. Tätä työnantajan oikeutta suojataankin liikkeen luovutuksen yhteydessä siten, ettei työntekijällä ole oikeutta vastustaa siirtymistä jäämällä luovuttajan palvelukseen. ${ }^{\mathbf{3 8}}$

TSL 3:1 sisältää työntekijän yleisvelvoitteen, jonka mukaan "Työntekijän on tehtävä työnsä huolellisesti noudattaen niitä määräyksiä,joita työnantaja antaa toimivaltansa mukaisesti työn suorittamisesta. Työntekijän on toiminnassaan vältettävä kaikkea, mikä on ristiriidassa hänen asemassaan olevalta työntekijältä kohtuuden mukaan vaadittavan menettelyn kanssa." Liikkeen luovutustilanteessa työntekijän tulee siten noudattaa työntekoa koskevia luovuttajan määräyksiä työn tekemisestä ainakin, kunnes luovutuksensaaja antaa mahdollisesti uutta ohjeistusta työn suorittamiseksi. Myös TSL 3:1:een sisältyvän työntekijän lojaliteettivelvollisuuden työnantajaa kohtaan voidaan nähdä siirtyvän liikkeen luovutuksessa luovutuksensaajan hyväksi, jolloin myös lojaliteettivelvollisuus luovuttajaa kohden pääosin lakkaa.

Muita työnantajan oikeuksia, jotka siirtyvät automaattisesti liikkeen luovutuksen yhteydessä, on TSL 3:3:n mukainen työsuhteen aikainen kilpailukielto. Kilpailukielto on kuitenkin pitkälti sidottu työnantajan toimintaan, työntekijän asemaan sekä työn luonteeseen. ${ }^{39}$ Siten vaikka kilpailukielto siirtyy, voi se teoriassa muuttaa muotoaan liikkeen luovutuksen yhteydessä esimerkiksi työnantajan aseman muuttuessa kilpailuympäristössä liikkeen luovutuksen johdosta. Vain työnantajan kanssa kilpailevan toiminnan harjoittaminen on rajoitettua. Esimerkiksi jos luovutetaan tuotekehittely-yksikkö, jossa luovuttaja on toiminut lihanjalostuksessa ja luovutuksensaaja puolestaan tuottaa maitotuotteita, muuttaa tällöin myös työnantajan toiminta muotoaan. Tämä vaikuttaa siihen, millainen työnantajan kanssa kilpaileva toiminta on työntekijältä kiellettyä.

TSL 3:5:n mukaisen kilpailukieltosopimuksen siirtymistä voidaan kuvata ehdolliseksi verrattuna TSL 1:10.2:n pääsääntöön siirtymisen pakottavuudesta ja automaattisuudesta, sillä kilpailukieltosopimuksen tarkoitukseen nähden (työnantajan liiketoiminnan suojaaminen) se siirtyy pätevänä liikkeen luovutustilanteessa vain sillä ehdolla, että myös luovutuksensaajalla on siihen vetoamiseen oikeuttava erityisen painava syy. Luovuttajan ja luovutuksensaajan

37 Kairinen, Martti: 2. Työoikeuden normijärjestelmä. Teoksessa Koskinen, Seppo - Kairinen, Martti Nieminen, Kimmo - Nordstöm, Kim - Ullakonoja, Vesa - Valkonen, Mika: Työoikeus I. Alma Talent Oy, Helsinki 2017. Verkkojulkaisu, Alma Talent Fokus, päivitetty 20.10.2017, tarkistettu 21.5.2020. (Kairinen 2017a), Työnantajan käskyvallan perusteet; Käyttäytymisnormit.

38 Kairinen, Martti: Työoikeus perusteineen. Työelämän tietopalvelu Oy, Raisio 2009. (Kairinen 2009), s. 293.

39 Komulainen, Vesa.: Kilpailevan toiminnan kielto. Teoksessa Jalanko, Risto - Siiki, Marika (toim.) Helsingin hovioikeuden julkaisuja - Kirjoituksia työoikeudesta, s. 115-127. Hakapaino Oy, Helsinki 2009 (Komulainen 2009), s. 116-117. työnantajasubjektien erilaisuus voi vaikuttaa kilpailukieltosopimuksen pätevyyteen. Esimerkiksi työnantajan asema kilpailuympäristössä voi muuttua liikkeen luovutuksen yhteydessä, oikeuskäytännössä onkin mm. työnantajan pienen markkina-aseman on katsottu perustelevan paremmin kilpailukieltosopimuksen tarpeellisuutta. ${ }^{40}$

Yhteenvetona voidaan todeta, että monet työnantajan oikeudet siirtyvät automaattisesti luovutuksensaajan hyväksi. Ne voivat kuitenkin muuttaa muotoaan, vaikka TSL 1:10.2:n sanamuoto edellyttäisikin työsuhteen ehtojen siirtymistä sellaisenaan. Toisaalta säännöksen tarkoituksena on suojata työntekijän oikeuksia, eikä työntekijän velvollisuuksien sisällöllisen muutoksen voida välttämättä nähdä tätä tavoitetta vaarantavan. TSL 3:5:n mukainen kilpailukieltosopimus voidaan kuitenkin nähdä tässä yhteydessä poikkeuksellisena. Kilpailukieltosopimuksella on suora yhteys työntekijän oikeuksiin, vieläpä perusoikeuksiin ${ }^{41}$. Se, miten ja millaisena kilpailukieltosopimus siirtyy liikkeen luovutuksen yhteydessä, vaikuttaa suoraan työntekijän velvoitteisiin ja työnantajan oikeuksiin. Tästä syystä sääntelyä siirtymisestä tulisikin selkeyttää ainakin kilpailukieltosopimusten osalta.

\section{KILPAILUKIELTOSOPIMUS}

\section{I Kilpailukieltosopimus työsuhteen ehtona}

Kilpailukieltosopimus voidaan mieltää TSL 3:3:n mukaisen kilpailukiellon työsuhteen jälkeisen ajan sovituksi jatkumoksi. Kilpailukieltosopimuksella voidaan TSL 3:5:n asettamissa rajoissa sopia siitä, että työntekijä pidättäytyy työsuhteen päätyttyä työskentelemästä sopimuskumppanina olevan työnantajan kanssa kilpailevassa yrityksessä taikka aloittamasta itse työnantajansa kanssa kilpailevaa liiketoimintaa. Kilpailukieltosopimus tehdään siten työnantajan etujen suojaamiseksi. Kilpailukieltosopimuksessa sovitaan tavallisesti sen ajallinen soveltamisala, lisäksi voidaan sopia alueellisesta soveltamisalasta sekä eritellä kielletyt työtehtävät. ${ }^{42} \mathrm{Se}$ voi olla erillinen asiakirja taikka työsopimukseen kirjattu ehto. ${ }^{43}$ Kilpailukieltosopimuksen käsitettä on oikeuskäytännössä tulkittu laajasti. Se, että ehto ei suoraan kiellä, mutta kaventaa työntekijän oikeuksia toimia työnantajan kanssa samalla alalla työsuhteen päätyttyä, on katsottu

40 Mm. KKO 2014:50 perustelujen kohta 27. "Edellä todetuin tavoin K Oy:n toiminnassa on liike- ja ammattisalaisuuksiksi katsottavia tai niihin verrattavia tietoja, joita varten yhtiöllä on suojan tarve. Yhtio on verrattain pieni toimija alalla, minkä voi katsoa korostavan suojan tarvetta." Toisaalta ratkaisussa ltäSuomen HO S 18/384 perusteluissa yrityksen rakenteelle ja kyseisen toimialan kasvulle yrityksessà annettiin kilpailukieltosopimusta puoltava merkitys.

41 Perustuslain 18 §.

42 Saarinen, Mauri: Työsuhdeasioiden käsikirja I. Edita, Porvoo 2013 (Saarinen 2013), s. 808-809.

43 Esim. KKO 2014:50 oli työsopimuksen ehtona. 
kilpailukieltosopimukseksi. ${ }^{44}$ Vaikka kilpailukieltosopimus on työnantajan oikeus, pyritään TSL 3:5:ssä kuitenkin suojaamaan työntekijöitä liian pitkälle meneviltä rajoituksilta. ${ }^{45}$

Kilpailukieltosopimukset tulivat työoikeuden piiriin työsopimuslain muutoksella (724/1990) vuonna 1991 ja tällöin myös työoikeuden yleiset opit sekä periaatteet tulivat niiden osalta sovellettavaksi. ${ }^{46}$ Tätä ennen työsopimuslaissa säädettiin kilpailukieltosopimusten osalta sovellettavaksi lakia varallisuusoikeudellisista oikeustoimista. ${ }^{\mathbf{4 7}}$ Kilpailukieltosopimuksen ottamista osaksi työsopimuslakia perusteltiin hallituksen esityksessä mm. niiden yhä enenevällä yleistymisellä työsuhteissa. ${ }^{48}$

Kilpailukieltosopimusta ei tule mieltää tavallisena sopimusvapauden piiriin lukeutuvana sopimuksena, sillä kilpailukieltosopimusta solmittaessa ei voida nähdä sopimusoikeudelle tyypillistä asetelmaa kahdesta tasaveroisesta sopimusosapuolesta. Vaikka sen solmiminen onkin sekä vapaaehtoista että vapaamuotoista, rajoittavat sen solmimista TSL 3:5:ssä asetetut edellytykset. Kilpailukieltosopimus puuttuu perustavanlaatuisesti työntekijän oikeuksiin, sillä työntekijä sitoutuu työsuhteensa päätyttyäkin olemaan harjoittamatta työnantajansa kanssa kilpailevaa toimintaa. Tällöin työntekijä käytännössä luopuu osittain perustuslain 18.1 §:n mukaisesta oikeudestaan tehdä itse valitsemaansa työtä. Se, että työntekijä luopuu ns. luovuttamattomasta perusoikeudestaan, tekee kilpailukieltosopimuksesta poikkeuksellisen ehdon suhteessa muihin työsuhteessa vallitseviin ehtoihin. ${ }^{\mathbf{4 9}}$ Perustuslakivaliokunta on kuitenkin katsonut nykyisen TSL 3:5:n täyttävän perussoikeuden rajoituskriteerit ja olevan siten linjassa perustuslain kanssa. ${ }^{\mathbf{5 0}}$ Työntekijän elinkeinovapauden vastaparina tulee punnittavaksi työnantajan omistusoikeus liikesalaisuuksiinsa. ${ }^{51}$

Kilpailukieltosopimuksen perusoikeuksia kaventavasta vaikutuksesta johtuen lainsäätäjä on rajoittanut sen solmimismahdollisuuksia TSL 3:5:ssä usein eri keinoin. Kilpailukieltosopimuksen nojalla kielletyn toiminnan on ensinnäkin oltava työnantajan kanssa kilpailevaa. Sen solmiminen edellyttää työnantajan toimintaan tai työsuhteeseen liittyvää erityisen painavaa syytä kilpailukieltosopimukselle. Toiseksi, työsuhteen jälkeinen kilpailukielto on lain nojalla

44 KKO 2003:19

45 Saarinen 2013,801

46 Ks. hallituksen esitys laiksi työsopimuslain muuttamisesta (HE 57/1990 vp).

47 Sittemmin kumotun työsopimuslain (320/1970) 16.4 \&

48 HE $57 / 1990$ vp, s. 2

48 HE 57/1990 vp, s. 2.

Ks. Estlund, Cynthia L: Between Rights and Contract: Arbitration Agreements and Non-Compete Covenants as a Hybrid Form of Employment Law, 155 U. Pa. L. Rev. 379, 2006. (Estlund 2006).

50 Perustuslakivaliokunnan lausunto hallituksen esityksestä työsopimuslaiksi ja eräiksi siihen liittyviksi laeiksi (PeVL 41/2000 vp) s. $7-8$.

51 TEM 18/2018, s. 18 rajoitettu vain kuuteen kuukauteen ja enintään vuoteen, jos työntekijän katsotaan saavan tästä kohtuullinen korvaus ${ }^{\mathbf{5 2}}$. Kolmanneksi, kilpailukiellon ei katsota sitovan työntekijää, jos työsuhde päättyy työnantajasta johtuvasta syystä.

TSL 3:5:n edellyttämä työnantajan toimintaan tai työsuhteeseen liittyviä erityisen painavia syitä on lueteltu esimerkinomaisesti TSL 3:5.2:ssa. Näitä voivat olla liikesalaisuuden suojan tarve tai työnantajan työntekijälle kustantama erityiskoulutus ${ }^{53}$. Tämän lisäksi oikeuskäytännössä ja esitöissä on arvioitu erityisen painavan syyn täyttymistä erinäisissä tilanteissa. Myös työnantajan asiakassuhteiden suojaaminen ja työnantajan asiakkaiden liikesalaisuuksien suojaaminen voivat olla säännöksen tarkoittamia erityisen painavia syitä. Työsopimuslain esitöissä on korostettu, että erityisen painavan syyn täyttymistä tulee aina arvioida tapauskohtaisesti kokonaisharkintaa käyttäen. Esimerkiksi tutkimus- tai kehitystoimintaan liittyvässä työssä painavan syyn edellytyksen on arvioitu täyttyvän helpommin. Toisaalta taas suorittavaa työtä tekevän työntekijän kohdalla erityisen painavalta syyltä kilpailukieltosopimuksen solmimiselle edellytetään vielä suurempaa painavuuttajoko työnantajan toiminnan tai työsuhteen takia. ${ }^{\mathbf{5 4}}$ Erityisen painavan syyn arvioinnissa tulee siten aina ottaa huomioon myös työntekijän asema ja tehtävät. ${ }^{\mathbf{5 5}}$

Jos kilpailukieltosopimus on solmittu lain vastaisesti, on se TSL 3:5.5:n nojalla tältä osin mitätön. Kilpailukieltoon vaadittavan erityisen painavan syyn tulee olla voimassa sekä kilpailukieltopimusta solmittaessa että siihen vedottaessa ${ }^{\mathbf{5 6}}$ Kilpailukieltosopimus voi siten muuttua mitättömäksi ilman liikkeen luovutustakin, esimerkiksi olosuhteiden muutoksen johdosta. Alun perin pätevä kilpailukieltosopimus voi muuttua mitättömäksi, jos työntekijän ei enää asemansa muutoksen vuoksi katsota olevan avainasemassa suhteessa yrityksen asiakkaisiin taikka jos työntekijän kilpailukieltosopimus on perustunut esimiesasemaan ja tämä menetetään. Mikäli erityisen painavaa syytä sopimukselle ei enää ole, ei työnantaja voi siihen vedota. Se, että kilpailukieltosopimus voi muuttua mitättömäksi, suojaa työntekijää perusteetonta rajoitusta vastaan. Voidaan kuitenkin pohtia, toteutuuko suoja riittävästi käytännössä, kun tulkintaetu-

52 Artikkelin kirjoituksen jälkeen TEM on 9.42020 julkaissut luonnoksen hallituksen esityksestä laeiksi työsopimuslain 3 luvun 5 §:n ja merityösopimuslain 4 luvun 5 §:n muuttamisesta, jossa ehdotetaan kilpailukieltosopimusten korvattavuuden laajentamista koskemaan kaikkia kilpailukieltosopimuksia.

53 Erityiskoulutuksella tässä yhteydessä tarkoitetaan työnantajan kustannuksella työntekijälle järjestettyä koulutusta tai työnantajan koulutusta varten antamaa palkallista vapaata tai stipendiä. Erityiskoulutukseksi ei voida katsoa tavanomaista jatko- tai täydennyskoulutusta. Ks. HE 157/2000 vp s. 82

54 Esimerkiksi ratkaisussa RHO S 96/281 kilpailukieltosopimuksen solmimiselle ei ollut perustetta, kun kyse oli puhelinmarkkinointiyhtiössä työskentelevistä puhelinmyyjistä.

55 HE 157/2000 vp, s. 82.

56 Käy ilmi HE 157/2000 vp, s. 82 ja oikeuskäytännössä mm. KKO 2005:50. 
oikeus $^{57}$ kilpailukieltosopimuksesta on työsuhteen kestäessä työnantajalla ja työsuhteen päätyttyä sen pätevyys todetaan viime kädessä vasta tuomioistuimessa. ${ }^{\mathbf{5 8}}$

\subsection{Kilpailukieltosopimuksen työsopimussidonnaisuus liikkeen luovutuksessa}

Työoikeuden teorian sisällä on nähtävissä ero työsuhdeteorian ja työsopimusopin välillä. Vuorion 1950-luvulla edelleen kehittämä perussuhdeteoria ${ }^{\mathbf{5 9}}$ nojaa työsopimuksen sijaan työsuhteen käsitteelle ${ }^{60}$. Perussuhdeteorian mukaan työsuhde tulee nähdä ns. tyhjänä säiliönä, jota eri säännöstyskeinoista peräisin olevat normit jäsentävät. Näihin säännöstyskeinoihin lukeutuu osaksi myös työsopimus. ${ }^{\mathbf{6 1}}$ Työsopimus voidaan tällöin nähdä työnantajan ja työntekijän välisenä keinona sopia lain rajoissa yksityiskohtaisemmin kyseisen työsuhteen ehdoista. ${ }^{\mathbf{6 2}}$ Perussuhdeteorian mukaisessa työsuhteen jäsentämisessä kilpailukieltosopimus voidaan sijoittaa työsopimuksen kautta työsuhdetta normittavaksi säännöstyskeinoksi. Työsopimukselle perustuvasta työsopimusopista ${ }^{63}$ on pyritty työoikeudellisessa oikeuskirjallisuudessa erkaantumaan käyttämällä yhä enenevissä määrin työsuhteen käsitettä. Työsuhteen ehtojen nähdään vaikuttavan työsuhteessa ilman, että niiden tarvitsisi muuttua työsopimuksen osaksi. ${ }^{64}$ Työsopimus ja sen sisältämät ehdot työnteolle ovat siten vain osa työsuhteen tyhjäà säiliötä täydentävistä normeista. Kilpailukieltosopimuksen voidaan sen erityisedellytyksen - erityisen painavan syyn - vuoksi mieltää linkittyvän kuitenkin työsopimussuhteeseen. ${ }^{65}$

57 Työnantajan tulkintaetuoikeudella tarkoitetaan työnantajan oikeutta määrätä työsuhteen aikaisen oikeusnormin tulkinnasta, jota työntekijän tulee noudattaa. Mahdollinen tulkintaerimielisyys ratkaistaan vasta tuomioistuimessa. Ks. esim. Tiitinen - Kröger 2012, s. 323-325.

58 Koskinen 2004, s. 20

59 Sipilä 1938 ja Vuorio 1955.

60 Vrt. Ruotsi, jossa työsopimusoikeus nojaa työntekijän käsitteeseen. Tämä käy ilmi Ruotsin työntekijöiden suojelua koskevasta lain eli lag (1982:80) om anställningsskydd 1.1 §:stä.

61 Vuorio 1955 , s. 185 ja 403

62 Kairinen, Martti:1. Työsopimuksen tekeminen. Teoksessa Koskinen, Seppo - Kairinen, Martti - Nieminen, Kimmo - Nordstöm, Kim - Ullakonoja, Vesa - Valkonen, Mika: Työoikeus II. Alma Talent Oy, Helsink 2017. Verkkojulkaisu, Alma Talent Fokus, päivitetty 24.11.2017, tarkistettu 21.5.202O. (Kairinen 2017b), Työsopimuksen merkitys; Asettaa työehtoja.

63 Työsopimusopissa työsopimus muodostaa oikeussuhteen työnantajan ja työntekijän välille ja täss oikeussuhteessa vaikuttavat normit johtuvat suoraan työsopimuksesta. Siten, jotta ehdot tulisivat sovellettavaksi tassa kahdenkeskisessä oikeussuhteessa, tulisi niiden ensin muuttua tyosopimuksen osaksi. Työsopimusopin pohjautuessa työsopimukselle ei työsopimussuhteen nähdä pääsääntöisest jatkuvan ennallaan, mikäli suhteen toinen osapuoli vaihtuu. Työsopimuksen ehdot ovat siten voimassa sopimuksen osapuolten välillä sopimuksen voimassaolon ajan. Vrt. perussuhdeteoria, jossa esim. liikkeen luovutuksen yhteydessä työsuhteen katsotaan jatkuvan ennallaan, sillä työsuhde on tosiasiallisesti säilynyt samana tai samankaltaisena.

64 Esimerkiksi Murto 2015, s. 46-52. Vrt. Tiitinen - Kröger 2012, mm. s. 764 "käsitteelle työsuhde on perusteltua antaa tekninen merkitys." Tiitinen ja Kröger puoltavat siten kantaa, jonka mukaan esimerkiksi vakiintunut käytäntö tulee työsopimuksen osaksi. Oikeuskäytännössä linja on vaihdellut, mutta esim. HelHO S18/563 on arvioitu sitä, onko vakiintunut käytäntö tullut työsopimuksen osaksi.

65 Työsopimussuhteella tarkoitetaan tässä koko työsopimussuhteen kestoa, eikä ainoastaan ajanjaksoa työsopimuksen tekemisen ja työnteon aloittamisen välillä.
Myös Koskinen katsoo, että kilpailukieltosopimus on korostetun työsopimussidonnainen ehto. ${ }^{\mathbf{6 6}}$ Työsopimussidonnaisuudella tarkoitetaan tässä yhteydessä sitä, että jokin työntekijän ja työnantajan välistä suhdetta normittava ehto on voimassa työsopimuksen kautta siten, että se on riippuvainen työsopimuksen solmineiden osapuolten "henkilöstä".

Liikkeen luovutustilanteen oikeusvaikutukset on yleisesti helpompi jäsentää työsuhdeteorian kuin työsopimusopin kautta, sillä työsopimuskumppani vaihtuu, mutta työsuhteet säilyvät pääosin ennallaan. Liikkeen luovutustilanteita onkin käytetty työsuhdeopin puoltamiseen. ${ }^{\mathbf{6 7}}$ On kuitenkin huomattava, ettei työsopimusoppia voida näissä tilanteissa täysin sivuuttaa. Kilpailukieltosopimuksen ollessa korostetun työsopimussidonnainen ehto, tulisi sen ja liikkeen luovutuksen yhteyden käsittämiseksi operoida myös työsopimussuhteen käsitteellä. Työsopimussuhde katkeaa liikkeen luovutuksen yhteydessä, kun työsopimuskumppani vaihtuu ja kilpailukieltosopimuksen pätevyyttä on aina arvioitava työsopimuksittain. ${ }^{68}$

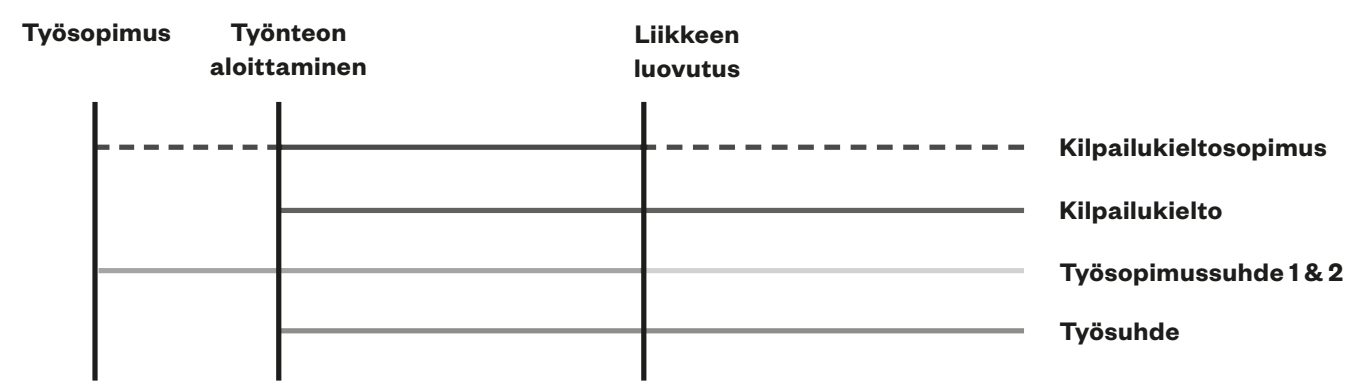

Kuvio 1: Kilpailukieltosopimuksen voimassaolo työsuhteessa sekä työsopimussuhteessa.

Kuvio 1 havainnollistaa työsuhteen ja osapuolten "henkilöihin" kiinnittyneen työsopimussuhteen eroa liikkeen luovutuksen yhteydessä. Jotta voidaan ymmärtää sovitun kilpailukieltoehdon muutos liikkeen luovutuksen yhteydessä, on nämä kaksi työntekijän ja työnantajan suhdetta jäsentävää kehikkoa erotettava toisistaan. Kilpailukieltosopimus on voimassa työntekijän ja luovuttajan työsopimussuhteessa. Liikkeen luovutuksen tapahduttua ei ole syytä kuitenkaan automaattisesti olettaa sopimuksen olevan voimassa sellaisenaan myös työntekijän ja luovutuksensaajan välisessä työsopimussuhteessa, vaikka työsuhde jatkuukin. Kuvio 1 esittää myös vertailun vuoksi TSL 3:3:ssä säädetyn työsuhteen aikaisen kilpailukiellon käytöksen liikkeen luovutustilanteessa. Kilpailukieltoehto siis siirtyy pääsäännön mukaisesti

66 Koskinen 2004, s. 9

67 Murto 2015, s. 50 ja Kairinen, Martti: Työoikeus ja perussuhdeteoria. Lakimies 2/1998, s. 193-210. (Kairinen 1998), s. 200. 
sellaisenaan liikkeen luovutuksen yhteydessä. ${ }^{69}$ Kilpailukielto kuitenkin eroaa työsuhteen ehtona kilpailukieltosopimuksesta. Kilpailukiellon voidaan nähdä ilmentävän työsuhteessa vallitsevaa molemminpuolista lojaliteettivelvoitetta ${ }^{\mathbf{7 0}}$, eikä sen voimassaolo ole samalla tavalla sidottu työsuhteen osapuolten "henkilöihin".

Kilpailukieltosopimuksen pätevyyden linkittyminen työsopimusosapuolten henkilöihin tekee siitä erityisen ehdon liikkeen luovutuksen yhteydessä. Kilpailukieltosopimuksen pätemättömyys voi johtua pelkästään työsopimussuhteen vaihdoksesta työsuhteen säilyessä ennallaan. Vaikka työsuhde sinällään pysyy samana, voidaan työsopimussuhteen nähdä muuttuvan, sillä sen toinen solmijaosapuoli eli muodollinen työnantaja vaihtuu liikkeen luovutuksen yhteydessä. Kilpailukieltosopimusta liikkeen luovutuksessa ei siten voida käsitellä ainoastaan työsuhdeteorian avulla, koska tällä ei voida riittävästi selittää sen mahdollista mitättömyyttä luovutuksensaajaan nähden. Ongelmaa tulee käsitellä myös työsopimussuhteen kautta. On huomioitava lisäksi, että myös saman työnantajan puitteissa työsopimussuhteen päättyminen, esimerkiksi työnantajan taholta tapahtuvalla osa-aikaistamisella, voi saada aikaan sen, ettei kilpailukieltosopimukseen ole mahdollista enää vedota, vaikka työsuhde periaatteessa jatkuukin. ${ }^{\mathbf{7 1}}$

\section{LIIKKEEN LUOVUTUKSEN VAIKUTUKSET KILPAILUKIELTOSOPIMUKSIIN}

\section{I Korkeimman oikeuden ratkaisu 2005:50}

Oikeuskäytäntö koskien kilpailukieltosopimusta liikkeen luovutuksen yhteydessä on varsin rajallista. Tätä selittää osittain se, ettei kilpailukieltosopimuksista haluta riidellä julkisesti ${ }^{\mathbf{7 2}}$ ja toisaalta se, että liikkeen luovutusproblematiikkaa koskevat riidat syntyvät useimmiten työntekijöiden eikä niinkään työnantajan oikeuksien säilymisestä. ${ }^{73}$ Käytännön tilanteissa esiin on noussut kysymys siitä, onko luovutuksensaaja oikeutettu vetoamaan luovuttajan ja työntekijän solmimaan kilpailukieltosopimukseen. ${ }^{74}$ Oikeuskäytännöstä voidaan johtaa yleisiä periaatteita aiheeseen liittyen, mutta koska kilpailukieltosopimusta koskevat ratkaisut ovat korostetun tapauskohtaisia, ei oikeustilaa voida yhden ennakkoratkaisun nojalla pitää selvänä.

69 Myös sopimuksen kilpailukieltoehdon poistamiseksi työsuhteesta on katsottu siirtyvän HelHO S 05/1399.

70 Työnantajalle kuuluvien työsuhteesta johtuvien oikeuksien siirtymistä käsitelty edellä kappaleessa 2.2.

71 Koskinen 2004, s. 10.

72 Ks. TEM 18/2018, s. 63-63 ja Koskinen 2004, s. 3.

73 Esim. työpoliittisessa tutkimuksessa työsopimuslain toimivuudesta 2004, eniten kysymyksiä lakimiesten keskuudessa liikkeenluovutustilanteiden vaikutuksesta työsuhteisiin herätti juuri työntekijöiden oikeuksien ja etujen siirtyminen, s. 51-54.

74 Esim. KKO 2005:50 sekä HelHO s 00/2395.
Korkeimman oikeuden ratkaisussa KKO 2005:50 käsiteltiin kilpailukieltosopimusta liikkeen luovutuksen yhteydessä. Tapauksessa oli kyse kauppahuonetoimintaa harjoittaneen yhtiön liikkeen luovutuksesta. Luovutuksen yhteydessä siirtyi myös tuotepäällikkönä toiminut työntekijä A, joka oli solminut luovuttajan kanssa kilpailukieltosopimuksen. Arvioitavaksi tuli lopulta se, oliko luovutuksensaaja oikeutettu vetoamaan kilpailukieltosopimukseen. Ratkaisussa on sovellettu vanhan työsopimuslain säännöksiä, mutta nämä vastaavat pääosin nykyisen lain säännöksiä TSL 3:55 sekä TSL 1:10.2.

Luovutuksensaaja (X Oy) oli nostanut kanteen entistä työntekijäänsä A:ta vastaan käräjäoikeudessa. Käräjäoikeuden ratkaisussa todettiin näytetyksi, että liikkeen luovuttajalla (Y Oyj) oli perusteet kilpailukieltosopimuksen solmimiselle A:n kanssa. Erityisen painavana syynä pidettiin asiakkaan säilyttämisintressiä. Ratkaisussa myös luovutuksensaajalla katsottiin olevan liikkeenluovutuksen jälkeen erityisen painava syy kilpailukieltosopimukseen vetoamiselle, ja täten sopimus ei ollut muuttunut mitättömäksi. Käräjäoikeus velvoitti A:n suorittamaan sopimussakkoa, joskin kohtuullistettuna. Hovioikeus pysytti käräjäoikeuden ratkaisun korostaen erityisesti A:n aseman merkitystä ja sitä, ettei kilpailukieltosopimus ollut kohtuuttomasti rajoittanut $A: t a$ hyödyntämästä ammattitaitoaan.

A:lle myönnettiin valituslupa korkeimpaan oikeuteen. Perusteluissaan korkein oikeus arvioi ensin solmitun "edustusten siirtymis- ja salassapitosopimus" -nimisen asiakirjan luonnetta. Korkeimman oikeuden perustelusta 1-6 käy ilmi, että oikeus on arvioinut sopimusta sen tarkoituksen perusteella, mikä viittaisi sopimusoikeudelliseen näkökulmaan. Sopimuksen tulkitseminen kilpailukieltosopimukseksi on linjassa lainsäädännön tavoitteiden kanssa. Ei olisi tarkoituksenmukaista, jos TSL 3:5:ää olisi mahdollista kiertää sopimuksen muodolla silloin, kun sopimuksen tarkoitus ilmeisesti on rajoittaa työntekijän elinkeinovapautta työsuhteen jälkeen. Sopimuksen tulkintaa kilpailukieltosopimuksena tukevat myös sopimusoikeuden yleiset opit, joiden mukaan sopimusta tulee tulkita ensisijaisesti sen tarkoituksen perusteella. ${ }^{\mathbf{7 6}}$ Sopimuksen luonne selvitetään siis ensin sopimusoikeudellisesti, minkä jälkeen korkein oikeus siirtyy arvioimaan sen pätevyyttä työoikeudellisten edellytysten nojalla. Perustelujen kohdissa 7-9 korkein oikeus toteaa, että liikkeen luovuttajalla on ollut erityisen painava syy kilpailukieltosopimuksen tekemiseksi. Syyksi on katsottu työntekijän edustuksellinen asema sekä työntekijälle tehtävässään kertyvät liikesalaisuudet. ${ }^{77}$ Nämä perusteet on mainittu myös esimerkkeinä TSL 3:5.2:ssa erityisen painavasta syystä.

75 HE 157/2000 vp, s. 81. Lain muutoksella pyrittiin kuitenkin työnantajan ja työntekijöiden etujen tasapuolisempaan huomioimiseen

76 Saarnilehto, Ari - Annola, Vesa: Sopimusoikeuden perusteet. Alma Talent Oy, Yhteistyössä Lakimiesliton Kustannus, Helsinki 2018. (Saarnilehto - Annola 2018), s. 160

77 On huomioitava, että ratkaisun antamisen jälkeen on säädetty myös liikesalaisuuslaki (595/2018). 
Perustelujen kohdassa 10 korkein oikeus ottaa kantaa kilpailukiellon siirtymiseen luovutuksensaajalle toteamalla, että "Kilpailukieltosopimukseen liittyvät työnantajan oikeudet ovat liikettä luovutettaessa työsopimuslain (320/1970) 7\$:n 2 momentin (235/1993) nojalla siirtyneet X Oy:lle muiden työsuhteeseen liittyneiden työnantajan oikeuksien tavoin." Kilpailukieltosopimuksen erityisluonteesta johtuen se on kuitenkin mitätön, jos myös luovutuksensaajalla ei ole siihen vetoamiseksi edellytettävää erityisen painavaa syytä - siten sen siirtymistä ei tulisi suoraan rinnastaa muiden työnantajan oikeuksien siirtymiseen, kuten korkein oikeus on ratkaisussaan tehnyt. ${ }^{\mathbf{7 8}}$ Korkein oikeus lausui perustelujen kohdassa 12, että " $Y$ Oyj:n ja A:n solmima kilpailukieltosopimus on kuitenkin $X$ Oy:hyn nähden pätevä vain, mikäli myös $X$ Oy:lä on sopimuksen voimassa pitämiseen työsopimuslain 16 a §̧:ssä edellytetty erityisen painava syy."79 Tässä tapauksessa korkein oikeus katsoi, ettei luovutuksensaajalla ollut erityisen painavaa syytä kilpailukieltosopimukseen vetoamiselle. Tapauksen ratkaisuun on kuitenkin vaikuttanut se, ettei A:n kilpailukieltosopimuksen perusteena ollut asiakassuhde siirtynyt luovutuksen yhteydessä luovutuksensaajalle. Ratkaisun perustelujen kohdasta 12 käy kuitenkin ilmi, että mahdollisesti myös muu syy kuin luovuttajan alkuperäinen erityisen painava syy kilpailukieltosopimuksen solmimiselle olisi voinut aiheuttaa sen, että luovutuksensaaja olisi ollut oikeutettu vetoamaan luovuttajan ja A:n välillä solmittuun kilpailukieltosopimukseen.

Voidaankin kysyä, miten kyseisen ratkaisun perustelut vastaavat liikkeen luovutussääntelyn tavoitteita. Punnittavana vastakkain ovat työntekijän oikeuksien turvaaminen sekä työnantajan oikeus liikesalaisuuksiensa ym. suojaan. Korkeimman oikeuden ratkaisu antaa ymmärtää, että merkittävämpänä tulee pitää työnantajan suojaa, kun kilpailukieltosopimukseen voi mahdollisesti vedota jopa uudella, sen solmimisen jälkeen liikkeen luovutuksen takia syntyneellä perusteella. ${ }^{\mathbf{8 0}}$ Kun kilpailukieltosopimuksen solmimisedellytyksistä on säädetty pakottavasti lailla, tulee niitä lähtökohtaisesti tulkita suppeasti. ${ }^{81}$ Tämän lisäksi kyseessä on rajoitus työntekijän perusoikeuteen ja näitä perusoikeuksia rajoittavia säännöksiä tulisi aina tulkita suppeasti. TSL 3:5:n sanamuoto ei sisällä indikaatiota siitä, että se voisi siirtyä toisen työnantajasubjektin hyväksi ja että erityisen painava syy voisi tällöin kaiken lisäksi muuttua. Tästä syystä korkeimman oikeuden ratkaisu mahdollistanee tulkinnan, joka laajentaa erityisen painavan syyn alaa liikaa työntekijän suojelun periaatteeseen ja supistavan tulkinnan vaatimukseen nähden.

Oikeuskirjallisuudessa kyseistä korkeimman oikeuden ratkaisua on kommentoitu hieman erilaisin nyanssein. Saarinen näkee ratkaisun merkityksen olevan se, "ettei työntekijän työsopimuksessa oleva kilpailukieltosopimus automaattisesti siirry luovutuksensaajan kanssa

78 Ks. kappale 2.2

79 Vrt. HelHO S 00/2395, jossa erityisen painavaa syytä ei edes arvioitu vaan sopimuksen katsottiin vain siirtyneen luovutuksensaajalle ja olleen siten pätevä.

80 TSL 3:5 tulkinnassa on myös oikeuskirjallisuudessa katsottu työnantajan etujen painavan punninnassa työoikeudessa vallitsevaa normaalia enemmän, esim. Tiitinen - Kröger 2012, s. 342.

81 Engblom 2013, s. 39 syntyvän työsopimuksen ehtoihin". ${ }^{22}$ Toisaalta Äimälä ja Kärkkäinen tulkitsevat, että liikkeen luovutuksessa kilpailukieltosopimus siirtyy ja "on voimassa luovutuksensaajan hyväksi, mutta olosuhteiden muuttumisesta voi seurata, ettei luovutuksensaaja voi vedota sopimukseen" ${ }^{83}$

Kilpailukieltosopimuksen erityisen painavan syyn korostetun tapauskohtainen arviointi aiheuttaa sen, ettei oikeustieteen kantaa tulisi perustaa yhden ennakkoratkaisun puitteissa käytävään keskusteluun. ${ }^{\mathbf{8 4}}$ Korkeimman oikeuden ratkaisussa on lisäksi sovellettu vanhaa työsopimuslakia, ja vaikka uusi kilpailukieltosopimusta koskeva säännös vastaakin asiallisesti vanhaa säännöstä, on sen tarkoituksena ollut työnantajan ja työntekijän etujen tasapuolisempi huomioon ottaminen. ${ }^{85}$ Kilpailukieltosopimusten käyttäytymistä liikkeen luovutustilanteissa tulisikin problematisoida laajemmin työoikeuden yleisten oppien näkökulmasta, työoikeudessa vallitsevia periaatteita unohtamatta.

\subsection{Työnantajan käsite liikkeenluovutustilanteessa kilpailukieltosopimuksen kannalta}

Se, miten työnantaja, jolle kilpailukieltosopimuksesta johtuva oikeus kuuluu, käsitetään, vaikuttaa siihen, miten ja millaisena sen katsotaan siirtyvän liikkeen luovutuksen yhteydessä. Työlainsäädännössä ei ole legaalimääritelmää työnantajan käsitteestä. Liikkeen luovutusta koskevassa oikeuskäytännössä työnantajasubjektin määrittelyä on käsitelty työnantajavastuun kannalta eikä niinkään työnantajan oikeuksien kautta. ${ }^{86}$ Onkin mielekästä pohtia, miten työnantaja tulisi määritellä suhteessa liikkeen luovutukseen ja kilpailukieltosopimukseen. Ratkaisussa KKO 2005:50 on työnantajana pidetty työoikeudelle tyypillisesti muodollista työnantajaa, yhtiötä. Ratkaisuun vaikutti kuitenkin myös se, että kilpailukieltosopimus ei siirtynyt yrityksessä tapahtuneen muutoksen (asiakassuhteen menettämisen) vuoksi. Siten muutos yritystoiminnassa, eikä vain työnantajayhtiössä, vaikutti kilpailukieltosopimuksen siirtymiseen

Mm. Kairinen ja Murto ovat erottaneet kaksi erillistä työnantajan käsitettä. Työnantaja voidaan nähdä työsopimusosapuolena, jolloin on useimmiten kyse yhtiöstä. Tätä kutsutaan muodolliseksi työnantajaksi. Toisaalta voidaan nähdä myös funktionaalinen, tosiasiallinen työnantaja, joka mielletään pikemminkin yritykseksi, liikkeeksi tai työpaikaksi ja on siten todellinen taloudellinen

82 Saarinen, Mauri: Työsuhteen pelisäännöt. Alma Talent Oy, Helsinki 2015. Verkkojulkaisu, Alma Talent Verkkokirjahylly, tarkistettu 18.5.2020. (Saarinen 2015), Työsopimuksen tekeminen; Työsopimuksen syntyminen liikkeen luovutuksen seurauksena.

83 Kärkkäinen - Äimälä 2017, s. 277.

84 Lähes poikkeuksetta oikeuskirjallisuudessa käsitellään liikkeen luovutuksen vaikutusta kilpailukieltosopimukseen pelkästään KKO 2005:50 kautta.

85 Kaivanto, Keijo: Kilpailukieltosopimuksen pätevyydestä. Teoksessa Saarnilehto, Ari (toim.): Työoikeus tänään. Juhlajulkaisu Martti Kairinen. Turun yliopiston oikeustieteellisen tiedekunnan julkaisuja, s. 41-50. tänään. Juhlajulkaisu Martti Kairinen. Turun yliopiston

86 Esim. TT:2013-152 koski irtisanomisjärjestystä konsernissa "Irtisanomisten taloudellisia ja tuotannollisia perusteita tulee lähtökohtaisesti arvioida sen yhtiön kannalta, joka muodollisesti on työnantajan." 
ja toiminnallinen kokonaisuus, jossa työtä tehdään. ${ }^{\mathbf{8 7}}$ Vaikka perinteisesti työoikeudessa työnantajaksi on käsitetty työsopimusosapuolena oleva muodollinen työnantaja, on kuitenkin nähtävissä kehitystä, jonka nojalla vallitsevaa tulkintaa voidaan kyseenalaistaa. ${ }^{\mathbf{8 8}}$ Juuri liikkeenluovutustilanteissa työsuhteet liitetään nimenomaan luovutettavaan liikkeeseen.

Yhtiö 1

Luovuttaja

Muodollinen työnantaja - työsopimuskumppani

Yhtiö 2

Luovutuksensaaja

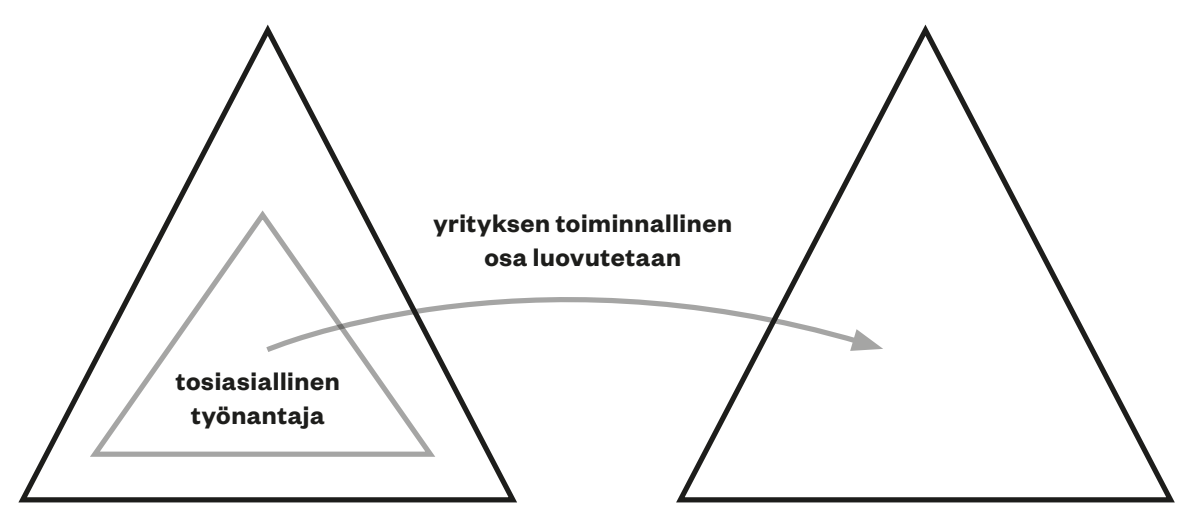

Kuvio 2: Yhtiö 1 luovuttaa yrityksen toiminnallisen kokonaisuuden Yhtiö 2:lle - myös tosiasiallisen työnantajan voidaan joissain tapauksissa katsoa siirtyvän osana kokonaisuutta.

Liikkeen luovutustilanteessa on selvää, että ainakin yleensä ${ }^{89}$ muodollinen työnantaja vaihtuu, kun tavallisimmassa tilanteessa liikkeen luovutuksessa on kyse toiminnallisen kokonaisuuden myymisestä toiselle yhtiölle. Voidaan kuitenkin pohtia, miten on laita tosiasiallisen työnantajan kannalta. Onhan liikkeen luovutuksen kriteerinä jo TSL 1:10.1:n nojalla, että liiketoiminta tai sen osa siirtyy toimivana kokonaisuutena luovutuksensaajalle. Liiketoimintakokonaisuuden tulee EUT:n oikeuskäytännön mukaan muodostua sellaisesta henkilöstöstä ja muista tekijöistä, jotka kykenevät harjoittamaan omiin itsenäisiin tavoitteisiin tähtäävää liiketoimintaa. ${ }^{90}$ Tähän itsenäiseen liiketoiminnan harjoittamisen kokonaisuuteen voidaan siten olettaa sisältyvän

87 Karinen, Martti: KKO ratkaisut kommentein I 2005:50. Teoksessa Timonen, Pekka (toim.): KKO:n ratkaisut kommentein. Alma Talent Oy, Helsinki 2006. Verkkojulkaisu, Alma Talent Fokus, tarkistettu 8.5.2020. (Kairinen 2005), s. 49-51 ja Murto 2015, s. 75-77.

88 Esim. Huhtala, Seppo: Työnantajuus erityisesti konsernissa. Turun kauppakorkeakoulun julkaisusarja A-2:2002, Turku 2002. (Huhtala 2002), s. 191

89 Saarinen 2015, 2.2.6 Työsopimuksen syntyminen liikkeen luovutuksen seurauksena.

90 Asia C-13/95. Ayse Süzen v Zehnacker Gebäudereinigung GmbH Krankenhausservice. EU:O:1997:141 perustelujen kohta 13. jonkinasteinen työnantaja (joka valvoo ja ohjaa työntekoa ja jonka lukuun työ suoritetaan). Mikäli työnantaja mielletään pikemminkin liikkeeksi tai yritykseksi, voidaan työnantajan nähdä pysyvän pitkälti samana luovutuksesta huolimatta. Tätä teoriaa tukee myös ns. ankkuriteoria. ${ }^{91}$ Ankkuriteoriassa työntekijä säilyttää vanhan työntekijän asemansa, vaikka muodollinen työnantaja vaihtuukin liikkeen luovutuksen yhteydessä. Siten työsuhteen voidaan nähdä olevan olemassa pikemminkin työntekijän ja tosiasiallisen työnantajan välillä.

Työnantajan määritteleminen liikkeen luovutustilanteessa vaikuttaa siihen, miten tietyt työsuhteiden ehdot siirtyvät. Kun kilpailukieltosopimuksen tarkoituksena on suojata juuri työnantajan intressejä, voidaan kilpailukieltosopimuksen siirtymistä pätevänä sopimuksena puoltaa ainakin silloin, jos työnantajaksi määritellään tosiasiallinen työnantaja. Tällöin työnantajan toimintaan perustuvasta erityisen painavasta syystä solmitun kilpailukieltosopimuksen voitaisiin nähdä olevan voimassa edelleen saman työnantajan hyväksi, vaikkakin siihen vetoamiseen olisi muodollisena työnantajana oikeutettu luovutuksensaaja yhtiö. Toisaalta kilpailukieltosopimus on korostetun työsopimussidonnainen ehto. Kilpailukieltosopimus on alun perin sovittu työntekijän ja muodollisen työnantajan kesken. Työsopimussuhde kuitenkin vaihtuu liikkeen luovutuksen yhteydessä. Jos työnantaja käsitetään liikkeen luovutuksessa muodollisena työnantajana eli työsopimuskumppanina, voidaan kilpailukieltosopimuksen siirtyminen sellaisenaan kyseenalaistaa. ${ }^{\mathbf{2}}$

Työnantaja olisi mielekästä käsittää liikkeen luovutustilanteissa kilpailukieltosopimusten kannalta tosiasiallisena työnantajana, sillä tämä kuvaa paremmin asioiden todellista luonnetta. Mikäli siis tosiasiallinen työnantaja pysyy samana liiketoimintakokonaisuuden luovutuksessa, on perusteltua, että myös kilpailukieltosopimuksen vetoamiseen oikeuttava erityisen painava syy säilyisi. Silti vallitseva käsitys muodollisesta työnantajasta tukee paremmin työntekijän suojelun periaatetta. Tällöin kilpailukielto ei siirtyisi automaattisesti, eikä siten työnantajan määritelmän kautta laajennettaisi erityisen painavan syyn soveltamisalaa.

\subsection{Erityisen painavan syyn merkitys}

Kilpailukiellon siirtymiseen liikkeen luovutustilanteessa voidaan nähdä vaikuttavan myös sen, millä perusteella kilpailukieltosopimus on solmittu, sillä erityisen painavan syyn täyttymistä edellytetään myös kilpailukieltosopimukseen vedotessa. ${ }^{93}$ Onkin mielekästä pohtia liikkeen luovutuksessa siirtyviä erilaisten erityisen painavien syiden nojalla solmittuja kilpailukieltosopimuksia. Kilpailukieltosopimuksen tulee perustua joko työnantajan toiminnasta tai työsuhteesta johtuvaan erityisen painavaan syyhyn. Liikkeen luovutuksen kontekstissa nämä molemmat voivat muuttua, toisaalta ne voivat myös pysyä lähes muuttumattomina.

91 Kairisen kehittämästä ankkuriteoriasta ks. Kairinen 2005, s. 54 ja Huhtala 2002, s. 191-193.

92 Näin esimerkiksi ratkaisussa KKO 2005:50.

93 Saarinen 2013, s. 802. 
Liikesalaisuudet ovat tavallisin syy kilpailukieltosopimuksen solmimiselle. ${ }^{\mathbf{9 4}}$ Liikesalaisuutta on tulkittu oikeuskäytännössä kilpailukieltosopimuksiin liittyen vaihtelevasti, joskus jopa määritelmää laajentavasti. ${ }^{95}$ Liikesalaisuuden määritelmä on sittemmin vahvistettu vuonna 2018 voimaan tullessa liikesalaisuuslaissa (595/2018). ${ }^{\mathbf{9 6}}$ Kyseisen lain voimaantulon yhteydessä muutettiin myös työsopimuslakia vastaamaan liikesalaisuuslaissa tarkoitettua liikesalaisuuden määritelmää. ${ }^{97}$ Luovutuksensaajalle voi liikkeen luovutuksen yhteydessä siirtyä myös liikesalaisuuksia. Voisikin olla perusteltua ajatella, että tähän syyhyn nojaava kilpailukieltosopimus olisi pätevä myös suhteessa luovutuksensaajaan - ovathan liikesalaisuudet usein tärkeä osa liiketoimintakokonaisuutta. Toisaalta esimerkiksi uusi liikesalaisuuksien suojaa paremmin turvaava liikesalaisuuslaki voisi vaikuttaa siihen, ettei luovutuksensaajalla enää olisi erittäin painavaa syytä aiemmin solmittuun kilpailukieltosopimukseen vetoamiselle, kun luovutuksensaajalla voisi olla muita vähemmän työntekijän oikeuksia rajoittavia keinoja suojella liikesalaisuuksiaan. ${ }^{\mathbf{9 8}}$

Kilpailukieltosopimukselle voidaan löytää perusteita myös yrityksen tarpeesta suojata asiakkaitaan tai asiakassuhteitaan. Asiakkaan säilyttämisintressi on usein syynä kilpailukieltosopimuksen solmimiselle työsuhteessa. Tähän voi liittyä työntekijän avainasema suhteessa yrityksen asiakkaisiin. Mikäli myös asiakkaat siirtyvät liikkeen luovutuksen yhteydessä, voitaneen ratkaisusta KKO 2005:50 tehdä vastakohtaispäätelmä, jonka mukaan tällöin luovutuksensaajalla olisi peruste vedota kilpailukieltosopimukseen. Kilpailukieltosopimukselle voidaan helpommin nähdä olevan erityisen painava syy, mikäli se solmitaan työnantajan ja työntekijän välillä yrityksen asiakkaiden liikesalaisuuksien suojaamiseksi. ${ }^{\mathbf{9 9}}$ Siten tähän perusteeseen nojaava kilpailukieltosopimus tulee arvioitavaksi suhteessa luovutuksensaajaan ennen kaikkea sen perusteella, siirtyvätkö myös luovutetun liikkeen asiakassuhteet luovutuksensaajalle. Asiakkaiden siirtyminen liikkeen luovutuksen yhteydessä on myös eräs liikkeen luovutuksen tunnusmerkki. ${ }^{100}$

\section{Heiskanen 2009, s.134.}

95 KKO 2003:19

96 Liikesalaisuuslain 2.1 " Tässä laissa tarkoitetaan liikesalaisuudella tietoa: a) joka ei ole kokonaisuutena tai osiensa täsmällisenä kokoonpanona ja yhdistelmänä tällaisia tietoja tavanomaisesti käsitteleville henkiloille yleisesti tunnettua tai helposti selville saatavissa; b) jolla a alakohdassa tarkoitetun ominaisuuden vuoksi on taloudellista arvoa elinkeinotoiminnassa; ja c) jonka laillinen haltija on ryhtynyt kohtuullisiin toimenpiteisiin sen suojaamiseksi".

97 HE 49/2018 vp - Hallituksen esitys liikesalaisuuslaiksi ja eräiksi siihen liittyviksi laeiksi, s. 115.

98 Kilpailukieltosopimusten pätevyyden arvioinnissa on oikeuskäytännössä arvioitu myös rajoituksen kohtuullisuutta sekä sitä, olisiko samaan lopputulokseen päästy myös vähemmin työntekijän elinkeinovapautta rajoittavalla keinolla, ks. esim. HelHO 29.11 .1989 S 89/234 ratkaisusta Koskinen 2004, s. 5.

99 HE 57/1990 vp, s. 4

100 HE 157/2000 vp, s. 66
Jos taas luovuttajan perusteena kilpailukieltosopimukselle olisi ollut työntekijälle kustannettu erityiskoulutus $^{101}$, ei tämän syyn nojalla voida välttämättä katsoa luovutuksensaajalla olevan oikeutta vedota kilpailukieltosopimukseen sen alkuperäisen solmimissyyn nojalla. Eihän luovutuksensaaja ole tällöin "uhrannut" mitään työntekijän eteen oikeuttaakseen kilpailukieltosopimuksen. Työntekijän suojelun periaatteesta johtuu, etteivät myöskään liikkeen luovutuksen kauppahinnassa mahdollisesti vaikuttavat erityiskoulutuksen kustannukset voi tätä kautta oikeuttaa kilpailukieltosopimukseen vetoamista tällä perusteella.

\section{EPÄSELVYYS KILPAILUKIELTOSOPIMUSTEN SIIRTYMISESTÄ}

\section{I Epäselvän oikeustilan ongelma}

Käytännössä kilpailukieltosopimus saatetaan lisätä osaksi työsopimusta varmuuden vuoksi. ${ }^{102}$ Vaikka työnantajan erityisen painavan syyn puuttuessa kilpailukieltosopimus on automaattisesti mitätön, voidaan työntekijän oikeusturvan silti nähdä vaarantuvan, mikäli hän ei osaa sopimuksen allekirjoitettuaan arvioida sen pätevyyttä tai mitättömyyttä. Työnantajan tulkintaetuoikeuden katsotaan olevan voimassa kilpailukieltosopimuksen osalta ainakin työsuhteen kestäessä, toisaalta työsuhteen päätyttyä tullee pitää oikeana sopimussidonnaisuuden rikkovaan toimintaan alkavan osapuolen käsitystä, jos asiaa ei riitauteta. ${ }^{103}$ Viime kädessä kilpailukieltosopimuksen sitovuus todetaan tuomioistuimessa.

Epäselvyyttä kilpailukieltosopimuksen pätevyydestä suhteessa luovutuksensaajaan lisää entisestään se, että TSL 3:5:n mukainen kilpailukieltosopimus on mahdollista tehdä vapaamuotoisesti, jopa konkludenttisesti ${ }^{104}$. Onko siten mahdollista, että työnantajan ja työntekijän välille voidaan katsoa syntyneen esimerkiksi työntekijän aseman nojalla hiljainen kilpailukieltosopimus? Tai voiko tällainen hiljainen kilpailukielto syntyä esimerkiksi liikkeen luovutuksen vaikutuksesta seuranneesta työntekijän aseman muutoksesta? Näin tuskin voidaan katsoa työntekijän suojan ja sopimusoikeuden yleisten periaatteiden valossa. Lisäksi prosessioikeuden normaalien käytäntöjen mukaan kilpailukieltosopimukseen vetoavalla työnantajalla on asiassa näyttötaakka. Tällöin työnantajalla voi olla vaikeuksia näyttää

101 Mikä on HE 157/2000 vp, s. 82, mukaan pätevä edellytys kilpailukieltosopimuksen solmimiselle. Mielenkiintoista on huomata, että tämä peruste ei esimerkiksi Yhdysvalloissa voi toimia erityisen painavana syynä.

102 TEM 18/2018, s. 61 ja 63

103 Koskinen 2004 s. 20.

104 Heiskanen. Saana: Hovioikeuskäytäntöä työoikeudellisista kilpailukieltosopimuksista. Oikeustieto 2/2015, s. 17-19. (Heiskanen 2015), s. 18 
konkludenttisesti syntynyt kilpailukielto toteen. ${ }^{105}$ Ylipäätään epäselvyyttä voi aiheuttaa sopimuksen luonne, kun kilpailukieltosopimukselle ei ole laissa asetettu muotovaatimuksia.

Työnantajan tulee TSL 2:4:n nojalla tiedottaa työntekijää työsuhteen ehdoista, jos ne eivät käy ilmi kirjallisesta työsopimuksesta. TSL 2:4.2 sisältää luettelon niistä ehdoista, joista on ainakin annettava selvitystä työntekijälle ja TSL 2:4.3:n mukaan työnantajan tulee ilmoittaa myös näiden ehtojen muutoksesta. ${ }^{106}$ Säännöksen luetteloa ei ole kuitenkaan tarkoitettu tyhjentäväksi. Oikeustieteessä ei vallitse yksimielisyyttä siitä, kuuluuko kilpailukieltosopimus näihin työsuhteen keskeisiin ehtomuutoksiin, joista työnantajan tulisi tiedottaa. Koskinen näkee kilpailukieltosopimuksen työsuhteen keskeisenä ehtona siten, että työnantaja olisi velvoitettu tiedottamaan siitä työntekijälle TSL 2:4:n edellyttämällä tavalla. ${ }^{\mathbf{1 0 7}}$ Heiskanen taas katsoo, että kilpailukieltosopimus ei kuulu työnantajan ilmoitusvelvollisuuden piiriin, koska sitä ei nimenomaisesti mainita TSL 2:4.2:n luettelossa. ${ }^{108}$ Kilpailukieltosopimuksen muutoksen tulisi sisältyäilmoitusvelvollisuuteenjo säännöksen sanamuodon perusteella. Kilpailukieltosopimushan on ehto, joka rajoittaa työntekijän perusoikeutta, jolloin sitä voi perustellusti pitää myös työsuhteen keskeisenä ehtona. Vaikka kilpailukieltosopimus katsottaisiinkin TSL 2:4:n ilmoitusvelvollisuuden piirin siten, että luovutuksensaajan tulisi ilmoittaa, mikäli sen suhteen on tapahtunut liikkeen luovutuksen yhteydessä muutoksia, ei työnantajalla kuitenkaan ole laista johtuvaa velvoitetta ilmoittaa työntekijälle kilpailukieltosopimuksen solmimiseen tai vetoamiseen oikeuttavaa erityisen painavaa syytä. ${ }^{109}$

Mielenkiintoisen ongelman synnyttää TSL 2:2.1:n työnantajalle asettama tasapuolisen kohtelun velvoite, jonka mukaan työnantajan tulee kohdella työntekijöitään tasapuolisesti, jollei sillä ole työntekijän tehtäviin tai asemaan perustuvaa syytä tästä poiketa. Tasapuolisen kohtelun velvoitteesta liikkeen luovutuksen yhteydessä annetussa ratkaisussa KKO 2004:103 velvoitettiin työnantaja yhtenäistämään vanhojen ja liikkeen luovutuksessa siirtyneiden työntekijöiden palkkausehtoja. ${ }^{110}$ Kilpailukieltosopimuksen ja työnantajan tasapuolisen kohtelun velvoitteen problematiikan on tuonut esille Murto. ${ }^{111}$ Kun tasapuolisen kohtelun velvoitteen merkitys työoikeudessa on kasvanut ja korkein oikeus on linjannut työnantajan velvollisuudeksi pyrkiä

105 Oikeudenkäymiskaaren (4/1734) 17:1, jonka mukaan riita-asiassa kantajan tulee näyttää toteen ne seikat, jotka tukevat kannetta.

106 HE 157/2000 vp, s. 71.

107 Koskinen 2004, s. 5 ja 9 myös kilpailukieltosopimuksesta vapautuminen.

108 Heiskanen 2009, s. 130

109 Vaikka esim. ylempien toimihenkilöiden neuvottelujärjestö on näin ohjeistanutkin, ks. Ylemmät toimihenkilöt YTN ry: Työsuhteeseen liittyvät kilpailunrajoitukset ja salassapito. Helsinki 2007. (YTN 2007), s. 11.

110 Vrt. Kultanen, Anna-Maija: Työsuhteen ehtojen yhtenäistäminen liikkeen luovutuksen jälkeen. Oikeustieto 6/2010, s. 13-16. (Kultanen 2010), s. 15, jossa ratkaisua on tulkittu siten, ettei ehtojen yhtenäistämistä välttämättä edellytetä, kun työnantajan mahdollisuudet tähän ovat vähäiset.

111 Murto, Jari: Kilpailukieltosopimukseen liittyvää viimeaikaista hovioikeuskäytäntöä. Oikeustieto 4/2009, s. 12-15. (Murto 2009), s. 15 yhtenäistämään liikkeen luovutuksesta johtuvia eroja työsuhteissa, voitaisiin tätä hyödyntää arvioidessa sitä, miten käy liikkeen luovutuksessa siirtyvän työntekijän kilpailukieltosopimuksen pätevyydelle. Mikäli luovutuksensaajan palveluksessa samassa asemassa siirtyvän työntekijän kanssa työskentelevillä työntekijöillä ei ole vastaavanlaisia kilpailukieltosopimuksia, voi tämä vaikuttaa arvioon kilpailukieltosopimuksen pätevyydestä suhteessa luovutuksensaajaan. Vaikutusta olisi todennäköisesti myös käytännössä, sillä erityisen painavan syyn näyttäminen voi olla näissä tilanteissa luovutuksensaajalle hankalaa.

\subsection{Oikeustilan selkeyttämisestä}

Vallitsevan oikeustilan mukaan työntekijän ja luovuttajan välillä solmittu kilpailukieltosopimus siis siirtyy (joskaan ei välttämättä pätevänä) automaattisesti työsuhteen ehtona liikkeen luovutuksen yhteydessä luovutuksensaajan hyväksi, työsopimussidonnaisuudesta huolimatta. Voidaan kuitenkin pohtia, vastaako nykyinen oikeustila liikkeen luovutusta koskevan säännöksen tavoitteita, joihin kuuluu työntekijän oikeuksien turvaaminen liikkeen luovutustilanteissa. Epäselvän oikeustilan ei voida myöskään nähdä turvaavan työnantajan etua, kun siirtyvän kilpailukieltosopimuksen pätevyydestä ei ole takeita.

Tämän vuoksi oikeustilaa tulisi selkeyttää esimerkiksi siten, että työnantajalla olisi liikkeen luovutuksen yhteydessä velvollisuus TSL 2:4:n nojalla tiedottaa kilpailukieltosopimuksen päättymisestä tai jatkumisesta. ${ }^{112}$ Pelkkä työntekijän epäilys työsuhteen jälkeisen kilpailukiellon pätevyydestä saattaa aiheuttaa sen, ettei työntekijä ota esimerkiksi työnantajan kilpailijan tarjoamaa työtarjousta vastaan. Tällöin kilpailukieltosopimus on palvellut luovutuksensaajan etua riippumatta siitä, onko se todellisuudessa pätevä vai mitätön. Toisaalta, perusteiltaan epävarma kilpailukieltosopimus ei ole luovutuksensaajankaan etu, lisäksi epävarmuus kilpailukieltosopimusten pätevyydestä aiheuttaa turhaa jäykkyyttä työmarkkinoille.

Yleisimmin kilpailukieltosopimus solmitaan työnantajan liikesalaisuuksien suojaksi. Näitä säätelevä liikesalaisuuslaki, jonka tarkoituksena on parantaa liikesalaisuuksien suojaa mm. selkeyttämällä lainsäädäntöä on tullut voimaan elokuussa 2018. Laki mahdollistaa yritykselle paremmat siviilioikeudelliset oikeussuojakeinot liikesalaisuuksiensa suojaamiseen. ${ }^{113}$ Jos uuden lain myötä työnantajan mahdollisuus suojata liikesalaisuuksiaan on siten parantunut, voidaan pohtia tulisiko kilpailukieltosopimuksia koskevaa sääntelyä uudistaa - jos työnantaja voi päästä oikeuksiinsa muuta, työntekijän perusoikeutta vähemmän rajoittavaa kautta. Perustellumpaa olisikin turvata liikesalaisuudet salassapitosopimuksella. Salassapitosopimuksella pikemminkin yksilöidään työntekijän lojaliteettivelvollisuuteen sisältyvä TSL 3:4:n mukainen liikesalaisuuden ilmaisukielto ${ }^{114}$,ja siten sen siirtymisestä liikkeen luovutuksen yhteydessä ei synny samanlaista

112 Täten kilpailukieltosopimuksen pätevyys tulisi todellisuudessa arvioiduksi.

113 HE 49/2018 vp, s. 69.

114 TEM $18 / 2018$, s. $26-28$ 
epäselvyyttä kuin kilpailukieltosopimuksesta. Tarkkarajainen salassapitosopimus hyödyttäisi työsuhteen molempia osapuolia ja turvaisi paremmin molempien osapuolten intressit liikkeen luovutuksen yhteydessä.

Kilpailukieltosopimuksia koskevaan sääntelyyn on ehdotettu tehtäväksi muutoksia vuonna 2017 lakialoitteella LA 90/2017 vp TSL 3 luvun muuttamiseksi. Huhtikuussa 2020 on julkaistu luonnos hallituksen esitykseksi kilpailukieltosopimusta koskevan sääntelyn muuttamiseksi. Esityksen tavoitteena on vähentää lain edellytysten vastaisesti solmittuja kilpailukieltosopimuksia, erityisesti niitä ennaltaehkäisemällä. ${ }^{115}$ Luonnos ei enää sisällä aiemmin ehdotettua säännöstä, jonka nojalla työnantajan tulisi antaa kirjallinen selvitys siitä, aikooko työnantaja vedota kilpailukieltosopimukseen, sekä yksilöidä tähän oikeuttava erityisen painava syy. ${ }^{116}$ Sen sijaan luonnoksessa ehdotetaan säädettäväksi kaikkia kilpailukieltosopimuksia koskeva korvausvelvollisuus. ${ }^{117}$ Hallituksen esityksen arvioidun esittelyviikon ollessa syksyllä 2020 sitä, miten kilpailukieltosopimuksia koskevaa sääntelyä tullaan lopulta uudistaman, on mahdotonta tässä arvioida.

\section{JOHTOPÄÄTÖKSET}

Vallitsevan oikeustilan mukaan kilpailukieltosopimukset siis siirtyvät luovutuksensaajalle kuten muutkin työnantajan oikeudet. Näin ei kuitenkaan todellisuudessa aina ole, sillä myös luovutuksensaajalla tulee olla erityisen painava syy sopimukseen vetoamiselle. Oikeustila on lisäksi epäselvä sen osalta, voiko luovutuksen saajan osalta erityisen painava syy olla mikä tahansa - eikä sen siten tarvitsisi olla sama kuin luovuttajalla kilpailukieltosopimusta solmittaessa. Tämä tulkinta ei vastaa työntekijän suojelun periaatteen mukaista supistavan tulkinnan vaatimusta.

Kilpailukieltosopimus on nähtävä työsopimussidonnaisena työsuhteen ehtona, sillä sen pätevyyteen erityisen painavan syyn edellytyksen kautta vaikuttaa suoraan sen solmijaosapuolten henkilöt. Liikkeen luovutus voi vaikuttaa näihin monella eri tavalla. Työnantajasubjektin vaihtuessa esimerkiksi kilpailuympäristö voi muuttua, jolloin myös sopimuksella kielletty työsuhteen jälkeinen kilpaileva toiminta muuttaa muotoaan. Toisaalta myös työntekijän asema

115 Luonnos 7.4.2020, s. 10.

116 LA 90/2017 vp - Lakialoite laiksi työsopimuslain 3 luvun muuttamisesta, s. 6. Sellaisenaan ehdotettu muutos olisi ollut parannus työntekijän suojaan myös liikkeenluovutustilanteissa. Työntekijä voisi luovutuksen tapahduttua tiedustella luovutuksensaajalta kilpailukieltosopimukseen oikeuttavaa erityisen painavaa syytä, sekä aiotaanko sopimukseen vedota. Tällöin luovutuksensaajan tulisi liikkeen luovutuksen jälkeen tosiasiallisesti arvioida, onko kilpailukieltosopimuksen voimassa pitämiselle lain vaatimat edellytykset, ja ilmoittaa tästä työntekijälle.

117 Nykyisen TSL 3:5:n mukaan korvausvelvollisuus koskee vain kilpailukieltosopimuksia, joiden kesto on yli 6 kk työsuhteen päättymisestä. yrityksessä voi muuttua liikkeen luovutuksen yhteydessä, luovuttajan palveluksessa esimiehenä toiminut työntekijä saattaa menettää suhteellisen asemansa siirtyessään luovutuksensaajalle. Myös se, mihin erityisen painavaan syyhyn kilpailukieltosopimus on perustunut, vaikuttaa sen siirtymiseen. Kilpailukieltosopimuksen siirtyminen liikkeen luovutuksen yhteydessä tulisikin ymmärtää ehdolliseksi.

Kilpailukielto on nähtävä työnantajan oikeutena, jonka vuoksi on merkitystä sillä, miten määritellään työnantaja, jolle oikeus kohdistuu. Erityisen haasteellisen tästä käsitemäärittelystä tekee liikkeen luovutus, jossa liiketoimintakokonaisuus, joka on mahdollista nähdä työoikeudessa määriteltynä tosiasiallisena työnantajana, luovutetaan uudelle muodolliselle työnantajalle. Kun kilpailukieltosopimus on sidottu erityisen painavan syyn edellytyksen kautta työnantajaan, voidaan työnantajan käsitettä tulkitsemalla ratkaista sen siirtyminen pätevänä erilaisin tuloksin. Mikäli katsotaan, että tosiasiallinen työnantaja siirtyy liikkeen luovutuksen yhteydessä, ei välttämättä ole perustetta katsoa, etteikö tällöin myös kilpailukieltosopimus siirry pätevänä. Toisaalta on kiistatonta, että muodollinen työnantaja muuttuu liikkeen luovutuksen yhteydessä, jolloin TSL 3:5:n laajentava tulkinta pätevänä siirtymisestä ei pitäisi olla mahdollista. Näin on kuitenkin joissain tapauksissa katsottu, esimerkiksi Helsingin hovioikeuden ratkaisussa S $00 / 2395$.

Työsuhteen osapuolten etuja ei palvele epäselvä, oikeuskäytännön varaan jätetty oikeustila. Tilanteeseen voisi tuoda edes osittaisen parannuksen kilpailukieltosopimuksen ottaminen osaksi TSL 2:4:n työnantajan ilmoitusvelvollisuutta. Tästä ilmoitusvelvollisuudesta voitaisiin lisäksi säätää tarkemmin liikkeen luovutuksen osalta, kun on selvää, etteivät työsuhteen ehdot siirry TSL 1:10.2:n pääsäännön mukaisesti poikkeuksetta. Myös kilpailukieltosopimuksen painavan syyn edellytyksiä tulisi tarkistaa mm. uuden liikesalaisuuslain myötä erityisesti, kun tutkimukset ovat osoittaneet niitä käytettävän liian laajasti työsuhteissa. Oikeustilaa onkin viimein ehdotettu selkeytettäväksi lakimuutoksella.

Olisikin suotavaa, että lainsäätäjä puuttuisi myös kilpailukieltosopimusten ja liikkeen luovutuksen tulkintaongelmiin. Kilpailukieltosopimukseen liittyvä perusoikeuspunninta toisaalta työntekijän elinkeinovapauden ja toisaalta työnantajan omistusoikeuden välillä edellyttäisi lainsäädäntöä, eikä asian jättämistä oikeuskäytännön varaan. Erityisesti kun otetaan huomioon molempien ilmiöiden laajemmat taloudelliset ja yhteiskunnalliset vaikutukset, olisi perusteltua, että kilpailukieltosopimusten siirtymisen kriteereistä liikkeen luovutuksen yhteydessä säädettäisiin suoraan laissa. Vähintäänkin lainsäätäjän tulisi selkeyttää työnantajan informaatiovelvollisuutta liittyen kilpailukieltosopimuksiin liikkeen luovutuksen yhteydessä. 